\title{
Experimental evaluation of the grazing optimization hypothesis
}

\author{
SAMUEL C. WILLIAMSON, JAMES K. DETLING, JERROLD L. DODD, AND MELVIN I. DYER
}

\begin{abstract}
The herbivore grazing optimization hypothesis predicts an increase in aboveground net primary productivity (ANPP) at a moderate grazing intensity. The hypothesis was tested by grazing controlled densities ( 0 to 145 individuals $\left./ \mathrm{m}^{2}\right)$ of big-headed grasshoppers (Aulocara elliotti Thomas) for short time spans (7 to 13 days) on enclosed swards $\left(0.7 \mathrm{~m}^{2}\right)$ of blue grama [(Bouteloua graclitis) (Willd. ex H.B.K.) Lag. ex Grifiths]. ANPP of each of 257 experimental enclosures was estimated following regrowth by using a standing crop index (the product of mean total blade length per tiller and percent basal cover) after the grazing period and clipping after the regrowth period. ANPP was not significantly reduced by grazing in any of the 5 short-duration grazing experiments. In 2 of the 5 experiments, ANPP increased significantly with graxing. In 1 of the other 3 experiments there was evidence for the grazing optimization hypothesis.
\end{abstract}

Key Words: graxing effects, Boutelowa gracilts, herbivore optimization hypothesis

The herbivore-plant relationship may be considered as a special case of the predator-prey system in which the logistic growth curve is most appropriate to describe primary productivity (Noy-Meir 1975, Caughley 1976). One prediction of such a model is that as herbivory reduces plant biomass from its maximum standing crop, plant productivity will increase. The herbivore grazing optimization hypothesis (McNaughton 1979, Hilbert et al. 1981) states that as grazing intensity increases, aboveground net primary productivity (ANPP) also increases up to some optimal grazing intensity, then decreases to a level below that of ungrazed plants (Fig. 1). Though commonly accepted for aquatic ecosystems (Carpenter and Kitchell 1984, Carpenter et al. 1985), this hypothesis is currently controversial for terrestrial ecosystems (Belsky 1986, 1987; McNaughton 1986).

Grasses are well adapted to regenerating biomass removed by grazing. Among grasses, shortgrasses are particularly adapted to grazing because their apical meristems are near ground level and less accessible to grazing animals (Dahl and Hyder 1977). Blue grama [(Bouteloua gracilis)(Willd. ex H.B.K.) Lag. ex Griffiths] is a warm-season dominant species of the shortgrass prairie (Detling 1979) that increases in relative abundance in heavily grazed areas and is adapted to extremes of environmental conditions. In this study, we evaluated the grazing optimization hypothesis for blue grama by examining its response to short-duration grazing events by big-headed grasshoppers (Aulocara elliotti Thomas) at different times during 2 different growing seasons.

\section{Study Area}

The study was conducted on the western edge of the USDA-

\footnotetext{
Authors are ecologist, U.S. Fish and Wildlife Service, 2627 Redwing Road, Fort Collins, Colo. 80526; senior research scientist, Natural Resource Ecology Laboratory, and associate professor, Department of Range Science, Colorado State University, Fort Collins 80523; professor, Range Management Division, University of Wyoming, Laramie 82071; and adjunct professor, Institute of Ecology. University of Georgia, Athens 30602. At the time of this study, Williamson and Dyer were graduate student and professor, respectively, Department of Fishery and Wildlife Biology, Colorado State University.

This research was supported by NSF grants DEB 76-82821 and BSR 84-06660.

Manuscript accepted 16 September 1988.
}

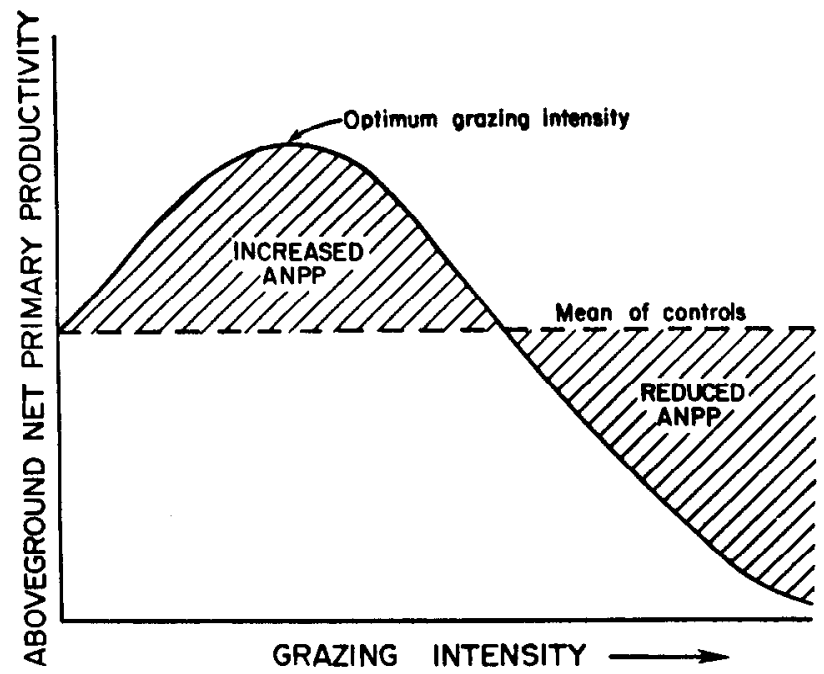

Flg. 1. The herbivore grazing optimization curve. A maximum value of aboveground net primary productivity (ANPP) is predicted at a moderate grazing intensity and a minimum value of $A N P P$ at a high grazing intensity.

ARS Central Plains Experimental Range in northcentral Colorado $\left(40^{\circ} 49 \mathrm{~N}, 104^{\circ} 47^{\prime} \mathrm{W}\right)$. Elevation is $1,650 \mathrm{~m}$, the topography is gently rolling plains, and the soil texture is sandy loam (Dickinson and Dodd 1976). Climate of the study area is continental with $82 \%$ of the mean annual precipitation occurring from 1 April to 30 September. Mean annual precipitation over a 31-year period was $310 \mathrm{~mm}$, with a range of $110 \mathrm{~mm}$ to $580 \mathrm{~mm}$ (Detling 1979). The experiments were conducted within a fenced pasture from which large herbivores had been excluded for the previous 10 years. Dominant species on this shortgrass prairie site were blue grama in association with buffalograss [Buchloë dactyloides (Nutt.) Engelm.].

\section{Methods}

Big-headed grasshoppers were chosen as the grazers because they are native to the shortgrass prairie and, with an average dry weight of $0.1 \mathrm{~g}$, are an appropriate size for use in a large number of small experimental units. In addition, they feed well on blue grama, survive well with handling, and are available for mass collections as fourth or fifth instars or adults from early June (from southern locations) through mid-August (Capinera and Sechrist 1981).

Wooden frame cages with inside measurements of $0.83 \mathrm{~m}$ by 0.83 $\mathrm{m}$ by $0.5 \mathrm{~m}$ high were covered with aluminum wire screen and placed on all plots (including the controls) immediately preceding each experiment. Placement sites were chosen randomly, except for avoiding woody shrubs, buffalograss, or disturbances such as ant mounds or rodent burrows. Prior to initial placement of the cages, plant species other than blue grama (always less than $10 \%$ of standing crop) were removed from the plot. Mean soil water content ( 2 readings from 3 access tubes) of the $15-$ to $60-\mathrm{cm}$ layer was measured biweekly with a neutron probe. Water content of the 0 -to 

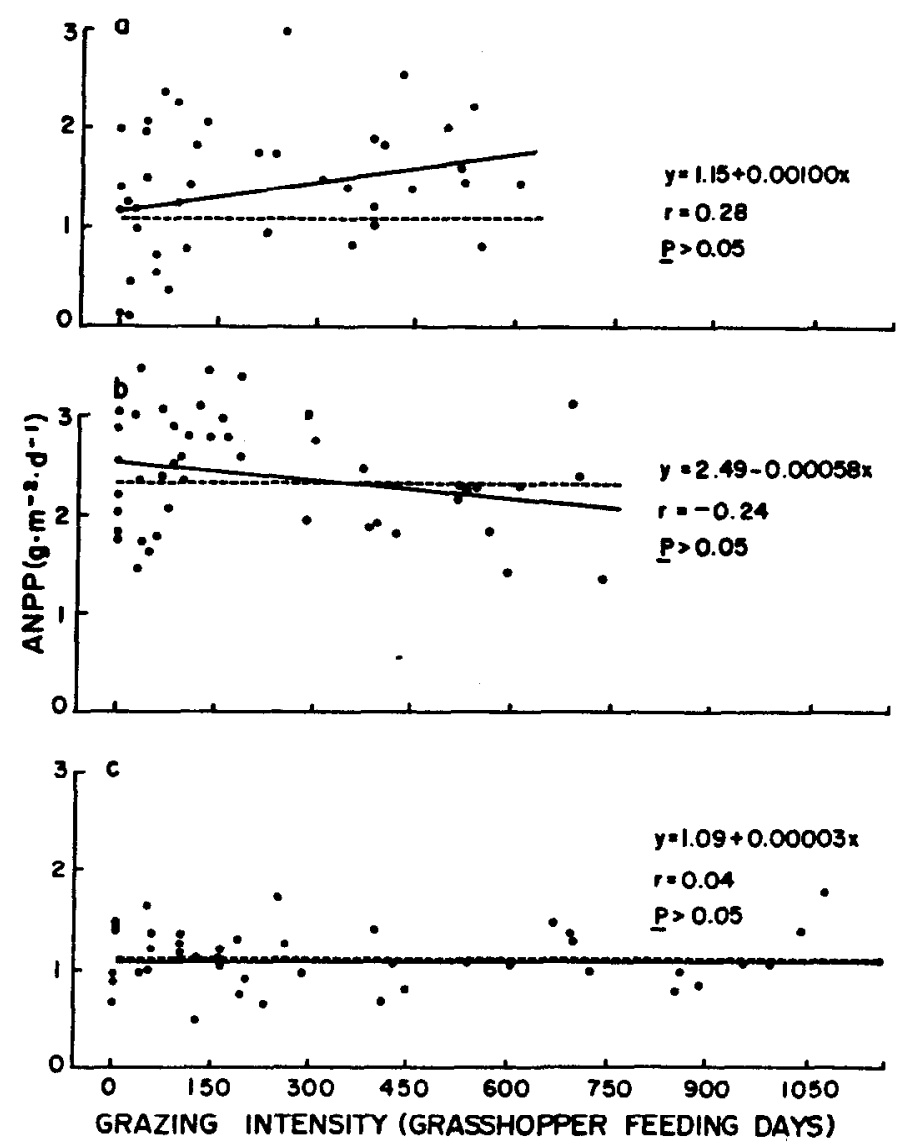

Fig. 2. Blue grama aboveground net primary productivity (ANPP) on areas subjected to varying intensities of grazing during the periods (a) 20 June to 18 July 1979, (b) 24 July to 22 August 1979, and (c) 26 August to 6 October 1979. Dashed lines are means of controls; solid lines are linear regressions.

$15-\mathrm{cm}$ layer was not included because of the unreliability of this method at shallow depths.

A nondestructive technique was used to estimate the aboveground standing crop of blue grama immediately before and after grazing. A square wood frame with an inner grid comprised of 16 strings set at $10-\mathrm{cm}$ intervals along both axes of the frame was placed $4 \mathrm{~cm}$ above the ground. Basal cover of tillers was measured to the nearest millimeter along each string, for a total of $13.3 \mathrm{~m}$ of line measurements per quadrat. At alternate intersections of 2 strings, the nearest blue grama tiller was selected, and length $(\mathrm{mm})$ of each blade was recorded. Vegetation on calibration plots was measured for blade lengths and basal cover, clipped at ground level, and oven dried at $60^{\circ} \mathrm{C}$ for 72 hours. Calibrations of the standing crop index (percent basal cover $\bullet$ mean total blade length per tiller) vs. plant biomass were obtained by using a least squares fit of a zero-intercept linear regression. This methodology is more fully described and representative calibration plots are given in Williamson et al. (1987).

Treatments were assigned randomly to the experimental units and consisted of caged and ungrazed (controls) or caged and grazed plots. In 1979, we utilized 6 control plots and 5 plots each of 8 levels of grazing intensity. Grazing intensities were based on stocking densities of $5,10,15,20,40,60,80$, or 100 grasshoppers per cage. Based on analysis of the 1979 data, the experimental design for 1980 was modified to increase the number of control plots to 13. The treatment with 15 grasshoppers per cage was eliminated in the June 1980 experiment and, in addition, the treatment with 5 grasshoppers per cage was eliminated in July 1980.

Because weather-dependent grasshopper mortality occurred during the grazing period, a grazing intensity index, grasshopper feeding days, was computed as the product of length of the grazing event (days) and average number of grasshoppers in the cage during that period. Average number of grasshoppers per cage was determined by counting grasshoppers as they were placed on and removed from the plots, and assuming a linear decrease in density for those which disappeared by the time of removal. This was considered a reliable index of grazing intensity (or pressure) within an experiment but not between experiments. Use of this index assumes a linear correlation between total grasshopper feeding days and blue grama biomass removed, although this assumption may not be true at very high grasshopper densities (Hewitt et al. 1976).

Only 1 grazing event was conducted on each plot. The chronology of each experiment included: (1) nondestructive biomass measurements before grazing; (2) a 7-to 13-day grazing period, which was terminated when the most intensely grazed plots were $95 \%$ denuded; (3) nondestructive biomass measurements 2 to 7 days after grazing; (4) a 13-to 41-day regrowth period; and (5) a destructive biomass measurement. Grazing periods in the 5 experiments were: 10 to 17 June $1979 ; 12$ to 20 July 1979; 11 to 24 August 1979; 15 to 26 June 1980; and 22 to 31 July 1980 . Biomass harvests at the end of the regrowth periods were made on: 16 to 20 July $1979 ; 16$ to 31 August 1979 (interrupted by cold, wet weather); 6 to 7 October 1979; 23 to 26 July 1980; and 13 to 14 August 1980 . Mean ANPP (mass area $^{-1} \cdot$ time $^{-1}$ ) was calculated as in Hunt (1978) by dividing the change in biomass by the number of days in the regrowth period.

Since the presence of a parabolic curve was hypothesized (Fig. 1), response surface techniques were adopted to better define the actual response curve (Ostle and Mensing 1975). Individual linear regression analyses were conducted in which tests for differences between treatment means were followed by tests of the slope of the best fit least squares regression line. Before conducting the analyses, the data were examined for homogeneity of variance. Mean ANPP in each treatment and experimental data were compared. Student's t-test was used to test for individual differences between graphically identified treatment means (Ostle and Mensing 1975), using $\alpha=0.05$ as the significance level. Finally, ANPP was plotted against grasshopper feeding days for each experiment, and the graphs were examined for lack of goodness of fit of a zero-slope line whose intercept was the mean value of the ungrazed plots.

\section{Results and Discussion}

The mean biomass $(\bar{x} \pm 1$ SD) prior to grazing on all experimental plots from the June, July and August 1979 and June and July 1980 experiments was $49.8( \pm 18.9) \mathrm{g} \bullet \mathrm{m}^{-2}, 71.8( \pm 21.9) \mathrm{g} \bullet \mathrm{m}^{-2}$, $33.9( \pm 14.8) \mathrm{g} \bullet \mathrm{m}^{-2}, 105.8( \pm 17.3) \mathrm{g} \bullet \mathrm{m}^{-2}$, and $136.6( \pm 26.2)$ $\mathrm{g} \bullet \mathrm{m}^{-2}$, respectively. No significant effect of grasshopper grazing on ANPP of blue grama was found in the June and August 1979 sampling periods (Fig. $2 \mathrm{a}$ and $2 \mathrm{c}$ ). In the latter case, cool weather apparently retarded feeding. In the two 1980 experiments, ANPP across all grazing intensities was significantly greater than ANPP of the ungrazed controls (Fig. 3).

In the case of the July 1979 experiment (Fig. 2b), there was evidence for the hypothesized (Fig. 1) grazing optimization curve. In this experiment, only 2 observations in the range of 100 to 300 grasshopper feeding days (corresponding to 20 and 40 grasshoppers per cage) were below the mean ANPP of controls, while 9 values were above the controls. In the range of 300 to 800 grasshopper feeding days (60,80 and 100 grasshoppers per cage), only 3 values were above the mean control ANPP, and 8 values were 


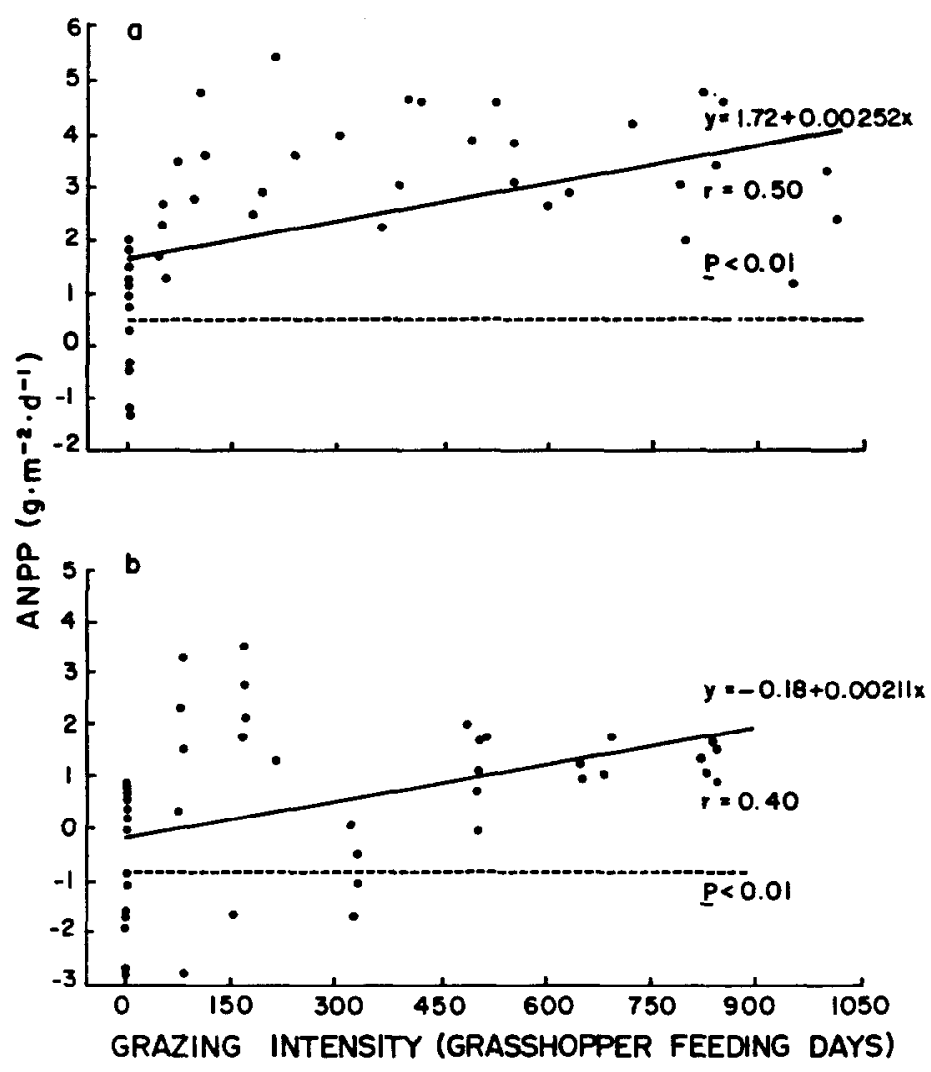

Fig. 3. Blue grama aboveground net primary productivity (ANPP) on areas subjected to varying intensities of grazing during the pertods (a) 28 June to 24 July 1980, and (b) 31 July to 13 August 1980. Dashed lines are means of controls; solid lines are linear regressions.

below it. The means of these 2 sets of values were significantly different from each other $(t=3.36,23$ d.f., $P<0.01)$. As with the 2 other 1979 experiments, ANPP across all grazing treatments did not differ significantly from that of the ungrazed controls.

The accuracy and precision of measurements of ANPP depend not only on changes in biomass but on length of the regrowth period. Thus, when determining mean daily rates of change, if some factor such as soil water or temperature is limiting, the calculated rate may be unrealistically reduced by including a time period when little or no growth is occurring. In the experiment with the longest regrowth period (41 days), and including a time period when temperature limited growth, ANPP was low with noticeably less treatment variability (Fig. 2c).

The within-year and between-year variability of ANPP (Figs. 2 and 3) indicates that weather effects should be considered when evaluating grazing effects. Soil water content in the $15-$ to $60-\mathrm{cm}$ depth varied significantly within and between growing seasons (Fig. 4). Soil water content of the $15-$ to $60-\mathrm{cm}$ section decreased from approximately $21 \%(95 \mathrm{~mm})$ to $13 \%(60 \mathrm{~mm})$ during the regrowth period in both the June and August 1979 experiments (Fig. 4, lines a and c). During regrowth in the July 1979 experiment (Fig. 4, line b), soil water content increased from $12 \%(55 \mathrm{~mm})$ to $21 \%(95 \mathrm{~mm})$. In the regrowth periods following both 1980 experiments, soil water content remained relatively constant at $16 \%(70$ $\mathrm{mm}$ ) and $14 \%(65 \mathrm{~mm})$, respectively (Fig. 4, lines $\mathrm{d}$ and $\mathrm{e}$ ).

Understanding the interactive effects of soil water content and grazing intensity is essential to understanding the relationship of grazing intensity and blue grama ANPP. Similar results between the June and August 1979 experiments and between the June and July 1980 experiments may be attributable to similar soil water
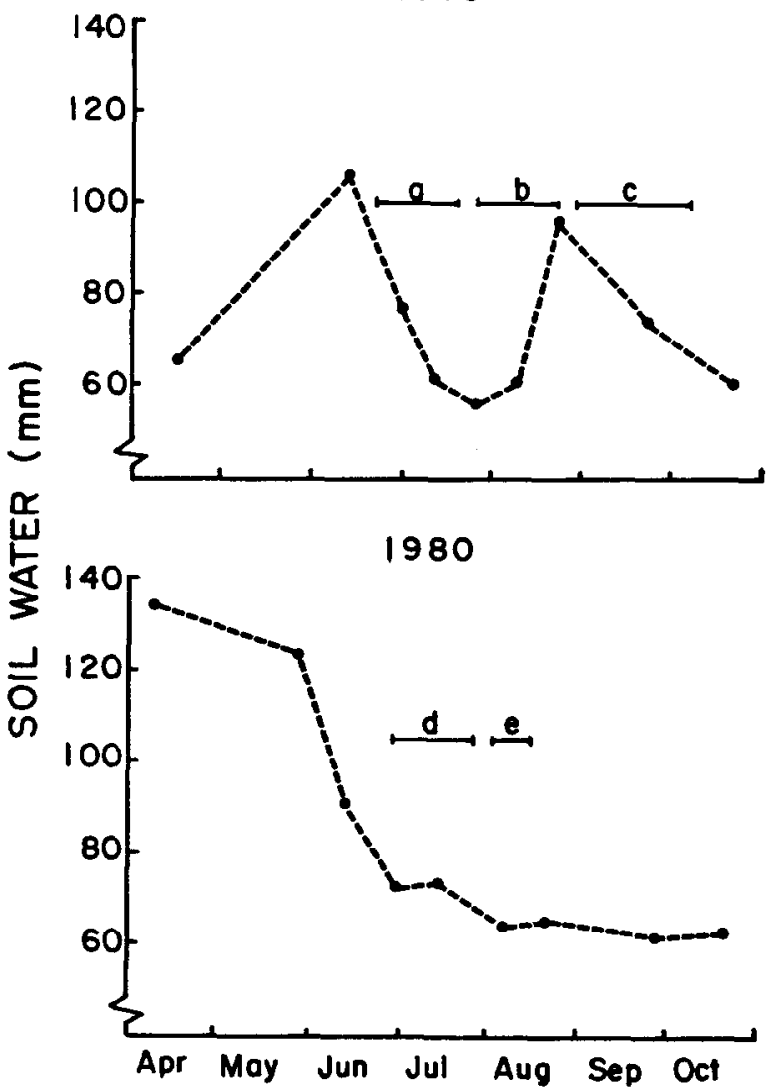

Fig. 4. Soil water content from neutron probe measurements in the 15- to $60-\mathrm{cm}$ soil section for the 1979 and 1980 growing seasons. Lines $a, b$, and $c$ represent the duration of the regrowth period following the June, July, and August 1979 grazing experiments. Lines $d$ and e represent the duration of the regrowth period following the June and July 1980 grazing experiments.

content patterns in the respective regrowth periods. Maximization of productivity with a moderate amount of grazing may occur under certain soil water conditions. Hodgkinson (1976) found that Danthonia caespitosa plants which were completely defoliated once during the summer and not irrigated increased shoot yield, but similarly defoliated plants "which were irrigated decreased shoot yield compared with undefoliated plants. After precipitation following dry conditions, production on lightly to moderately grazed areas frequently exceeds that on ungrazed or heavily grazed areas (McNaughton 1976, Heitschmidt et al. 1982). Thus, herbivore grazing optimization of shortgrass ANPP appears most likely to occur during recovery from a dry period.

Although this experimental work is based on a single grass species and a single herbivore species, it has broader ecological implications. In none of 5 experiments did a short-duration grazing event reduce ANPP of blue grama compared with ungrazed areas. When soil water content was moderate and constant through the regrowth period, all intensities of grazing resulted in equivalent ANPP that was significantly greater than ungrazed areas. This was an unexpected and interesting variation of the herbivore optimization curve. Following summer drought, light to moderate levels of grazing resulted in a significantly greater ANPP than did heavy levels of grazing.

\section{Literature Cited}

Belsky, A.J. 1986. Does herbivory benefit plants? A review of the evidence. Amer. Natur. 127:870-892. 
Belsky, A.J. 1987. The effects of grazing: Confounding of ecosystem, community, and organism scales. Amer. Natur. 129:777-783.

Caughley, G. 1976. Plant-herbivore systems. p. 94-113. In: R.M. May (ed.) Theoretical ecology: Principles and applications. W. B. Saunders Co., Philadelphia.

Capinera, J.L., and T.S. Sechrist. 1981. Grasshoppers (Acrididae) of Colorado: Identification, biology and management. Colorado State Univ. Exp. Sta. Bull. 584S. Fort Collins.

Carpenter, S.R. and J.F. Kitchell. 1984. Plankton community structure and limnetic primary production. Amer. Natur. 124:159-172.

Carpenter, S.R., J.F. Kitchell, and J.R. Hodgaon. 1985. Cascading trophic interactions and lake productivity. BioScience 35:634-639.

Dahl, B.E., and D.N. Hyder. 1977. Developmental morphology and management implications. p. 257-290. In: R.E. Sosebee (ed.) Rangeland plant physiology. Soc. Range Manage. Denver, Colo.

Detling, J.K. 1979. Processes controlling blue grama production on the shortgrass prairie. p. 25-42. In: N.R. French (ed.) Perspectives in grassland ecology: Results and applications of the US/IBP Grassland Biome Study. Springer-Verlag, New York.

Dickinson, C.E. and J.L. Dodd. 1976. Phenological patterns in the shortgrass prairie. Amer. Midl. Natur. 96:367-378.

Heitschmidt, R.K., D.L. Price, R.A. Gordon, and J.R. Frasure. 1982. Short duration grazing at the Texas Experimental Ranch: Effects on aboveground net primary production and seasonal growth dynamics. J. Range Manage. 35:367-372.
Hewitt, G.B., W.H. Burleson, and J.A. Onanger. 1976. Forage losses caused by the grasshopper Aulocara elliotti on shortgrass rangeland. J. Range Manage. 29:376-380.

Hilbert, D.W., D.M. Swift, J.K. Detling, and M.I. Dyer. 1981. Relative growth rates and the grazing optimization hypothesis. Oecologia 51:14-18.

Hodgkinson, K.C. 1976. The effects of frequency and extent of defoliation, summer irrigation, and fertilizer on the production and survival of the grass Danthonia caespitosa Gaud. Aust. J. Agr. Res. 27:755-767.

Hunt, R. 1978. Plant growth analysis. The Camelot Press, Ltd, Southampton.

McNaughton, S.J. 1976. Serengeti migratory wildebeest: Facilitation of energy flow by grazing. Science 191:92-94.

McNaughton, S.J. 1979. Grazing as an optimization process: Grassungulate relationships in the Serengeti. Amer. Natur. 113:691-703.

McNaughton, S.J. 1986. On plants and herbivores. Amer. Natur. 128:765-770.

Noy-Meir, 1. 1975. Stability of grazing systems: An application of predator-prey graphs. J. Ecol. 63:459-481.

Ostle, B., and R.W. Mensing. 1975. Statistics in research. Iowa State University Press, Ames.

Williamson, S.C.1983. The herbivore optimization hypothesis: A sampling design, experimental examination and simulation. Ph.D. Diss., Colorado State Univ., Fort Collins.

Williamson, S.C., J.K. Detling, J.L. Dodd, and M.I. Dyer. 1987. Nondestructive estimation of shortgrass aerial biomass. J. Range Manage. 40:254-256. 